\title{
Bioleaching of Metals from Wastes of Phosphoric Fertilizers Production
}

\author{
Akmaral U. Issayeva ${ }^{1}$, Radosław Pankiewicz ${ }^{2 *}$, Ainagul A. Otarbekova ${ }^{1}$ \\ ${ }^{1}$ M. Auezov South Kazakhstan State University, Taukekhan Avenue 5, 160012 Shymkent, Kazakhstan \\ ${ }^{2}$ Adam Mickiewicz University in Poznan, Uniwersytetu Poznanskiego 8, 61-614 Poznan, Poland
}

Received: 18 October 2019

Accepted: 19 February 2020

\begin{abstract}
Phosphorus-containing wastes formed after the production of phosphorus fertilizers in Shymkent, due to intensive urbanization were within the city limits and for reason of processes of water-wind erosion began to pose a serious threat to the environment and the population of the city. It was found that the formation of the fractional composition of wastes was influenced by the conditions of processing of raw materials, weather and climatic parameters and time characteristics of storage. The greater part of the waste are silicate and calcium-containing compounds. One of the options for waste disposal is considered the possibility of bio-leaching of valuable components from it. The choice of phase 1 nitrifies and micromycetes is justified by neutral or slightly acidic $\mathrm{pH}$ values of their cultivation, which will allow to abandon the use of acidophilic bacteria or sulfuric acid leaching. A variant using a strain of acidophilic bacteria Alicyclobacillus tolerans ST confirmed the effectiveness of their use in the bioleaching of magnesium, aluminum, potassium, calcium, phosphorus, REE such as lanthanum, cerium and neodymium. The use of micromycete Aspergillus niger AsIA proves its effectiveness in the extraction of zirconium and silver. The use of nitrifying bacteria Methyloversatilis thermotolerans MSO increases the extraction of barium and iron.
\end{abstract}

Keywords: bioleaching, phosphorus containing waste, Alicyclobacillus tolerans, Aspergillus niger, Methyloversatilis thermotolerans

\section{Introduction}

Mining and processing of mineral metal-containing raw materials is aimed, mainly, on the extraction of one component. As a result, most of the valuable metals go to wastes. At the same time, intensive urbanization processes lead to the fact that the boundaries of residential places are gradually beginning to absorb

*e-mail: e-mail: radek@px.pl the territory of industrial wastes storage. Gradually the accumulated and stored in the open-air wastes begin to represent a serious threat to the environment and, in particular, to public health. At the same time, wastes are the complex of valuable components suitable for further use.

It is known a number of studies devoted to the behavior of rare earth elements in phosphorite ores $[1,2]$ and natural water [3-5]. It was investigated the possibility of rare earth elements composition obtaining from deposits in the Southwestern Sinai, the characterization of the residue shows the presence of 
uranium, rare-earth elements (REE), aluminum, and zinc that can be valorized [6].

From the known phosphate raw materials that are processed for fertilizers, apatite concentrates containing about $0.9 \%$ of rare earth elements $[7,8]$ is of the greatest practical value as a source of rare earth elements. In phosphorites, the content of rare earth elements is significantly lower and usually does not exceed $0.1 \%$ and their extraction is associated with certain technological difficulties $[9,10]$.

According to [11] one of the cost-effective and environmentally friendly methods of processing lowgrade raw materials, which can include waste processing of ores, is bioleaching. However, it is known that the biological leaching allows extracting of REE from raw materials by using of microorganisms composition that destroy the metal-containing minerals by oxidizing of ferrous iron to ferric iron, and sulfur of mineral sulfides to sulfuric acid and converting the metals from the minerals into solution. Under mesophilic conditions, acidophilic thionic bacteria, which are used in hydrometallurgy, play a leading role in oxidative processes [12-14]. Most commonly used for bioleaching are the bacteria Acidithiobacillus ferrooxidans [11, $15,16]$. The range of used in biohydrometallurgy microorganisms involves the application of Chromobacterium violaceum [17], Sulfobacillust hermosulfidooxidans [18, 19], Acidiphilium multivorum, Leptospirillum ferrooxidans [19, 20], Aspergillus niger [21]. At using of bacterial and micromycete cultures for the bioleaching of REE from phosphorus-containing wastes it was established the direct relationship between the volume of citric acid produced by the strain of Gluconobacteroxydans FCC and the degree of extraction of lanthanum [22]. There are studies related to the development of technology for the extraction of rare earth elements from phosphogypsum in situ [23]. On the other hand, at cultivation of microorganisms for bioleaching different nutrient media are used, which are certain solutions of salts with different $\mathrm{pH}$ values and which can also affect the metals, behavior.

More than 50.0 million tons of phosphoruscontaining wastes are stored on the territory of the South Kazakhstan region near Shymkent city, which, due to erosion processes, represent a serious threat to the environment and public health. The solution of this problem is important not only for Kazakhstan, but also for a number of countries with phosphoruscontaining waste in their territories. An especially acute environmental problem arises in the presence of concomitant radioactive elements, which complicates the implementation of waste recycling processes. In studies by Mäkinen et al. [2] the possibility of preliminary selective separation of uranium from phosphoruscontaining apatite ores with uranium impurities has been shown. It was found that the mixture used is fluorapatite and standard uranium ore and requires 24-hour sulfuric acid leaching at $\mathrm{pH}=1$ to obtain a $100 \%$ phosphorus yield. At the same time, $89 \%$ of uranium is dissolved in 3 days at $\mathrm{pH}>2$, and leaching is improved by the use of $\mathrm{Fe}^{3+}$ oxidizer. The maximum 95\% yield of uranium was observed with prolonged 28-day leaching. These studies show one of the ways to solve the problem of utilization of phosphorus-containing slags. The possibility of reducing the processing time of metal-containing waste using an environmentally friendly method is shown in [12]. The authors argue that direct biological leaching of waste light-emitting

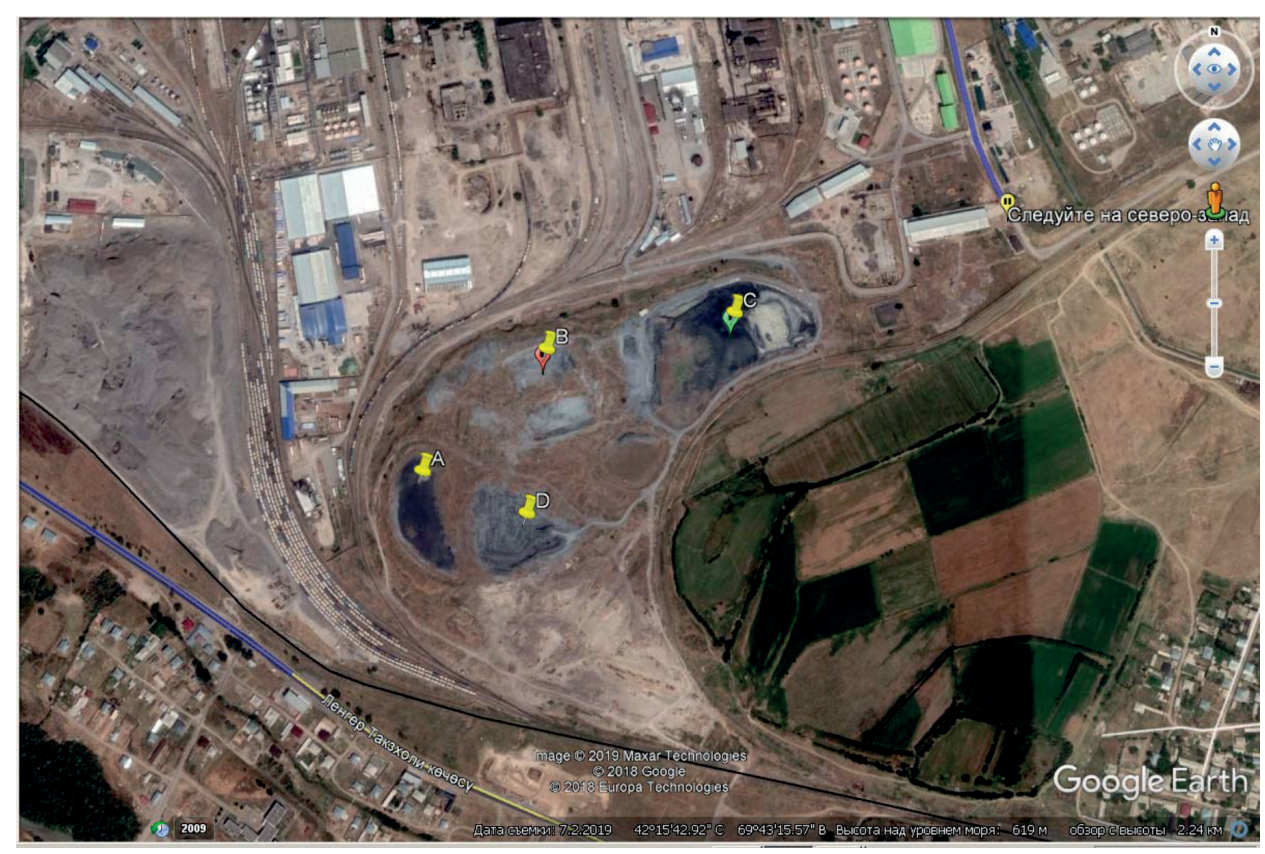

Fig. 1. Place of storage of phosphorus-containing waste in Shymkent: the markers shows the location of the sampling sites A, B, C, D (Google Earth, The view from the height: $2.24 \mathrm{~km}$ ). 
diodes (WLED) provides low yields of copper, nickel, and gallium, while detection of all metals is improved by phased indirect biological leaching. At a pulp density of $2 \mathrm{~g} / \mathrm{mL}$, the recovery efficiency of copper, Nickel and gallium is $83 \%, 97 \%$ and $84 \%$, respectively. The leaching time was reduced from 30 days to 15 days. From a technological point of view, the study showed that step-by-step indirect bioleaching with biogenic iron results in maximum recovery of valuable metals from WLED at low cost and through a short, simple and environmentally friendly process.

Each study shows the role of microorganisms in metal bioleaching processes, where microbial-free nutrient media variants or chemical analogues of microbial metabolites are used as controls. In our work the aim was to study the role of different ecological groups of microorganisms on the processes of extraction of metals from phosphorus-containing slags in Shymkent.

\section{Material and Methods}

The object of the study is phosphorus-containing wastes, the dumps of which in the amount of 50.0 million tons are located on the territory of Shymkent city (Fig. 1). Coordinates of the waste storage site: e.1. $42^{\circ} 15^{\prime} 42.92 \prime \prime$, n.1. 6943'15.57'". Height above sea level: $619 \mathrm{~m}$. Visually, phosphorus-containing slags can be divided into 4 conditional groups: A-light loose, B-dark loose, C-dark dense, D-light dense (Fig. 2).

The studies used strains of sulfur-oxidizing bacteria - Alicyclobacillus tolerans ST (sin. Sulfobacillus thermosulfidooxidans), micromycete Aspergillus niger AsIA, bacterium Methyloversatilis thermotolerans MSO in the order Nitrosomadales.

Determination of $\mathrm{Fe}^{+} 2$ and $\mathrm{Fe}^{+} 3$ was carried out by a volumetric trilonometric method in technical solutions, which was distributed to measure the iron content in solutions in the range from 0.1-10 g/1 [24].

Inductively coupled plasma spectrometer with mass spectrometric detection of Varian-820 MS [25,26 ].

The elemental composition was determined by the method of atomic adsorption analysis on the spectrometer AAnalyst 800 (Perkin-Elmer) [27].

$\mathrm{X}$-ray diffractometric analysis was carried out on the automated diffractometer DRON-4 with $\mathrm{Cu}$ $\kappa \alpha$ - radiation, $\beta$-filter. Conditions for recording of diffraction patterns are: $\mathrm{U}=35 \mathrm{kV}$; I $=20 \mathrm{~mA}$; scale: 2000 impulse; time constant $2 \mathrm{~s}$; recording of theta-2theta; detector $2 \mathrm{deg} / \mathrm{min}$ [28].

Video fixation of the material was carried out with using of video card of electron-raster microscope JSM 649LV produced by the company JEOL (Japan) with the system of energy dispersive microanalysis INCA Energy 350 of the firm Oxford instruments (UK), associated with the system of structural analysis of polycrystalline objects HKL Basis.

\section{Microbiological Examination}

Sampling of water and ore was carried out by aseptic special samplers in accordance with the guidelines from the depths of 20-40 cm.

For the cultivation of sulfur-oxidizing bacteria used Vaxman's medium ( $\mathrm{g} \backslash 1$ water): $\left(\mathrm{NH}_{4}\right)_{2} \mathrm{SO}_{4}-0.2$; $\mathrm{MgSO}_{4} \times 7 \mathrm{H}_{2} \mathrm{O}-0.5 ; \mathrm{KH}_{2} \mathrm{PO}_{4}-3.0 ; \mathrm{CaCl}_{2} 6 \mathrm{H}_{2} \mathrm{O}-$ $0.25 ; \mathrm{FeSO}_{4} \times 7 \mathrm{H}_{2} \mathrm{O}-0 ., 0001, \mathrm{~S}^{\circ}-10 . \mathrm{pH} \mathrm{3,0}$. For the cultivation of micromycetes Chapek's medium was used, g/l of water: sucrose -30.0 or glucose -20.0 ; $\mathrm{NaNO}_{3}-2.0 ; \mathrm{K}_{2} \mathrm{HPO}_{4}-1.0 ; \mathrm{MgSO}_{4} \times 7 \mathrm{H}_{2} 0-0.5 ; \mathrm{KC} 1$ $-0.5 ; \mathrm{FeS}_{4} \times 7 \mathrm{H}_{2} 0-0.1$. For cultivation of 1 phase nitrifying bacteria the Vinogradsky's medium was used, g/l of water: glucose $-20.0 ; \mathrm{K}_{2} \mathrm{HPO}_{4} .1 .0 ; \mathrm{MgSO}_{4} \times 7 \mathrm{H}_{2} 0$ -0.5 ; $\mathrm{CaCO}_{3}-20.0$; yeast extract -10.0 ; the solution of microelements $-1.0 \mathrm{ml}$.

The bacteria required for biological leaching were inoculated on the selective nutrient medium in the thermostat of the brand №TS-1/80 SPU TU 9452-002-00141798-97. The process of cultivation was continuously aerated. At the nutrient medium preparation the scale of the brand "Scout-Pro" was used, and for sterilization the autoclave of the brand SPGA100-I-HHwas used. Cultivation of microorganisms was carried out at $25^{\circ} \mathrm{C}$ for 7 days.

\section{Molecular Genetic Identification of Bacteria Strains}

Taxonomic analysis of isolated microorganisms was carried out by PCR analysis. Genomic DNA was isolated from diurnal bacterial cultures using the PureLink Genomic DNA Kit according to the manufacturer's protocol (Invitrogen, Carlsbad, USA). The concentration of DNA and the PCR product in the samples was determined on a Qubit ${ }^{\circledR} 2.0$ fluorimeter
A

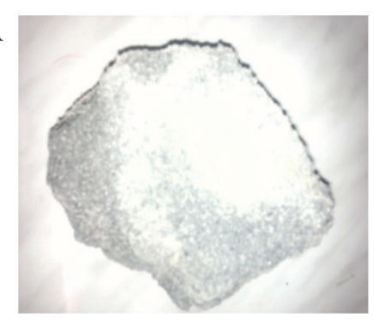

B

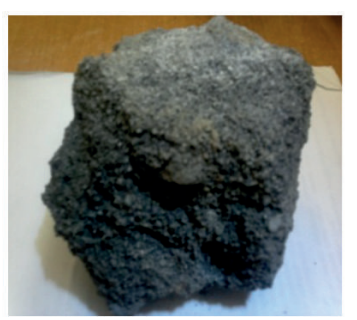

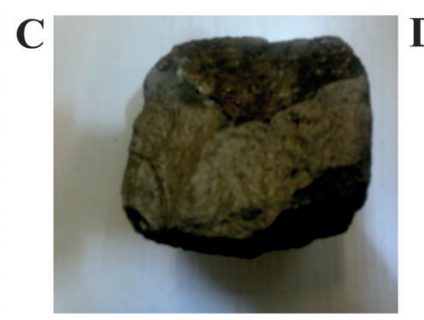

Fig. 2. Types of phosphorus containing wastes. 
using the Qubit TMds DNA HS Assay Kit (Life Technologies, Oregon, USA).

PCR was performed on an Eppendorf ProS amplifier (Hamburg, Germany) with an amplification mode: $94^{\circ} \mathrm{C}-30 \mathrm{sec} ; 55^{\circ} \mathrm{C}-1 \mathrm{~min} ; 72^{\circ} \mathrm{C}-40$ sec. - only 30 cycles; $72^{\circ} \mathrm{C}-10 \mathrm{~min}$. Amplification results were viewed on a $1.2 \%$ agarose gel. PCR products were purified by CleanSweep TM PCR Purification reagent (ApplideBiosystems, USA).

\section{The Experiment Scheme}

Under model conditions, the influence of the composition of elective medium and microorganism's monocultures on the processes of metals leaching from phosphorus-containing wastes in percolation mode was studied. The experiment was carried out according to the scheme:

1. Nutrient medium of Vaxman
2. Nutrient medium of
Vaxman

+ Alicyclobacillustolerans ST;

3. $\mathrm{H}_{2} \mathrm{SO}_{4}-3,0 \mathrm{~g} / \mathrm{l}$.

4. Chapek's medium;

5. Chapek's medium + Asp. niger AsJA

6. Vinogradsky medium;

7. Vinogradsky medium + Methyloversatilis thermotolerans MSO+Pseudomonas stutzeri NJA.

Exposure period -30 days, the ratio $\mathrm{S}: \mathrm{L}=1: 3$. Temperature: $22-24^{\circ} \mathrm{C}$. The titer of microorganisms$10^{7}-10^{9} \mathrm{cell} / \mathrm{ml}$. The experiment was carried out in glass percolators.

\section{Statistical Analysis of the Results}

Experiments were carried out five times in repetition, calculate the standard $0.95>\mathrm{P}>0.80$. Statistical processing was performed using the statistical software package Microsoft Excel. By the number of measurements and in general diagnostic group determined the arithmetic mean [29].

\section{Results and Discussion}

The problem of recycling of metal-containing waste remains one of the acute environmental problems in many countries of the world. Of particular relevance is the issue of waste processing located near settlements. Such a picture has developed in the South of Kazakhstan, where due to intensive urbanization, the former territory of the plant for processing phosphoruscontaining raw materials into fertilizer was in the border of the city of Shymkent. Currently, an open landfill of phosphorus-containing waste with a volume of more than 50.0 million tons and occupying an area of more than 16.0 hectares poses a serious threat to the environment due to the processes of water and wind erosion, as well as the close location of underground and surface water sources. One of the first steps of studying

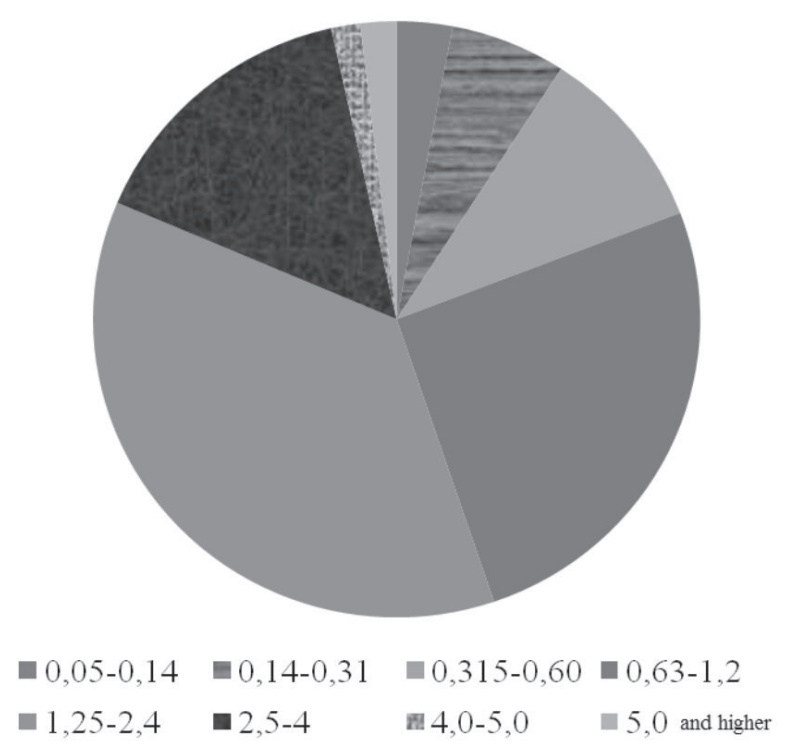

Fig. 3. Fractional composition of granulated phosphoruscontaining wastes [\%].

this problem was the study of physical and chemical characteristics of phosphorus-containing wastes.

The fractional composition of phosphorus-containing wastes at the storage sites was studied for research work. It is established that the granulated wastes differ by the dominant fractions (Fig. 3), while their formation is influenced not only by the technological parameters of the raw materials processing, but also by weather and climatic conditions and time characteristics of storage. At the storage sites, the dumps of phosphoruscontaining wastes are represented by the exhausted ores and pelletized slag, visually dominated by samples of size $10.0-18.0 \mathrm{~cm}$, occasionally samples of size up to $30.0 \mathrm{~cm}$ are marked. The mineralogical structure of the wastes is presented in Table 1.

The results show that the dominant part of the wastes consists of silicate and calcium-containing minerals. These minerals are represented by pseudowollastonite $\left(\mathrm{a}-\mathrm{CaOxSiO}{ }_{2}\right), \quad$ cuspidine $\left(3 \mathrm{CaOxCaF}_{2} \times 2 \mathrm{SiO}_{2}\right)$, ferrophosphorus $\mathrm{Fe}_{2} \mathrm{P}$, melilite $-\mathrm{Ca}_{2}(\mathrm{Al}, \mathrm{MgSi}) \mathrm{Si}_{2} \mathrm{O}_{7}$, akermanite - $\mathrm{Ca}_{2} \mathrm{MgSi}_{2} \mathrm{O}_{7}$, rankinite $3 \mathrm{CaOx} 2 \mathrm{SiO}_{2}$, fluorapatite $-\mathrm{Ca}_{5}\left(\mathrm{PO}_{4}\right) 3 \mathrm{~F}$, whitlockite $(\mathrm{NaF})$, fluorite $\left(\mathrm{CaF}_{2}\right)$ and silicocarnotite $\left(5 \mathrm{CaOx} \mathrm{P}_{2} \mathrm{O}_{5} \mathrm{xSiO}_{2}\right)$.

The elemental composition of the wastes varies in a wide range and depends on various factors such as the depth of wastes position in the dumps, the origin and type of wastes, the susceptibility to erosion processes, etc. The results of REM showed that the studied wastes differ not only visually, but also in the internal structure and content of individual elements (Fig. 4). So the content of such prevalent elements as phosphorus is found in the range of 0.50 to 21.95 weight $\%$, silicon content ranges from 1.16 to 13.49 weight $\%$; calcium content ranges from 0.42 to 25.37 weight \%, iron content is from 0.26 to 59.71 weight \%. Aluminum is presented more evenly in different types of wastes 
Table 1. Mineralogical structure of phosphoric wastes [wt \%].

\begin{tabular}{|c|c|c|c|c|c|c|c|c|c|}
\hline \multicolumn{2}{|c|}{ Compact wastes: } \\
\hline $\mathrm{SiO}_{2}$ & $\mathrm{CaO}$ & $\mathrm{Al}_{2} \mathrm{O}_{3}$ & $\mathrm{MgO}$ & $\mathrm{FeO}$ & $\mathrm{P}_{2} \mathrm{O}_{5}$ & $\mathrm{SO}_{3}$ & $\mathrm{~F}$ & $\mathrm{~S}$ \\
\hline $40.20 \pm 2.81$ & $48.46 \pm 4.22$ & $0.8 \pm 0.05$ & $4.07 \pm 0.41$ & $\begin{array}{c}\text { From trace till } \\
0.30\end{array}$ & $1.28 \pm 0.12$ & No trace & $2.85 \pm 0.22$ & No trace \\
\hline \multicolumn{7}{|c|}{ Granulated wastes } \\
\hline $42.68 \pm 4.05$ & $45.17 \pm 3.9$ & $2.88 \pm 0.21$ & $3.56 \pm 0.29$ & $\begin{array}{c}\text { from } 0.00 \text { till } \\
0.58\end{array}$ & $0.82 \pm 0.01$ & $\begin{array}{c}\text { from } 0.00 \text { till } \\
1.42\end{array}$ & $\begin{array}{c}\text { from } 0.00 \text { till } \\
1.95\end{array}$ & $\begin{array}{c}\text { from } 0.00 \text { till } \\
0.51\end{array}$ \\
\hline
\end{tabular}

Table 2. Elemental composition of phosphorus-containing wastes [ppb].

\begin{tabular}{|c|c|c|c|c|}
\hline Elements & $\mathrm{A}$ & $\mathrm{B}$ & $\mathrm{C}$ & $\mathrm{D}$ \\
\hline Te 125 & 1.23 & 1.28 & 0.42 & 1.20 \\
\hline La 139 & 282.85 & 462.72 & 8.03 & 14.83 \\
\hline Ce 140 & 283.49 & 480.68 & 17.13 & 18.60 \\
\hline Nd 146 & 222.60 & 379.02 & 12.94 & 12.87 \\
\hline Tm 169 & 2.74 & 4.78 & 0.05 & 0.15 \\
\hline Ta 181 & 0.72 & 1.61 & 3.20 & 1.48 \\
\hline Tl 205 & 0.61 & 0.96 & 0.10 & 0.30 \\
\hline Th 232 & 10.61 & 20.09 & 0.23 & 1.33 \\
\hline U 238 & 42.44 & 68.07 & 259.39 & 8.42 \\
\hline
\end{tabular}

from 0.31 to 1.2 weight $\%$, potassium is presented from 0.02 to 0.46 weight $\%$. Titanium, vanadium and chromium were observed only in one sample in the amount of $0.99 ; 0.25$ and 0.37 weight \% respectively. In all samples of phosphorus-containing wastes some rare earth elements were discovered, the amount of which ranges: lanthanum - from 8.03 to $462.71 \mathrm{ppb}$; cerium from 17.13 to $480.68 \mathrm{ppb}$; neodymium - from 12.87 to $379.02 \mathrm{ppb}$; thulium - from 0.05 to $4.78 \mathrm{ppb}$. In addition, such actinoids as thorium, the content of which in samples varies from 0.23 to $20.09 \mathrm{ppb}$ and uranium, the content of which in samples varies from 8.42-259.39 ppb, were noted. The contents of the individual elements are presented in Table 2.

The strains of microorganisms used in the studies are characterized by the following features: Alicyclobacillus tolerans ST (Sulfobacillus thermosulfidooxidans): is gram-positive, strictly aerobic bacterium. The bacteria are acidophilic and produced endospores. The optimum growth temperature for $A$. tolerans $S T$ is $37-42^{\circ} \mathrm{C}$, and can grow in the $20-50^{\circ} \mathrm{C}$ range. The optimum $\mathrm{pH}$ is 2.5-2.7, and can grow in $\mathrm{pH} 1.5-5.0$. It was first isolated from oxidizable lead-zinc ores in Uzbekistan [30, 31].

Methyloversatilis thermotolerans MSO - species from Nitrosomonale family, cells are Gram-stainnegative, non-motile rods $(0.3-0.4 \times 1.2-2.6 \mu \mathrm{m})$, that multiply by binary fission.

Aspergillus niger AsIA: the colonies color is from pure white to slightly yellowish, appearance is from woolly to velvety. The growth rate is moderate. The hyphae are septate and colorless. Conidial heads are spherical, with radial arrangement of conidia chains.

The main idea of the research was to study the role of isolated strains of microorganisms in the bioleaching of valuable components from phosphorus-containing slags of Shymkent, as was written above. The role of sulfobacteria in the bioleaching of a number of metals from both ores and man-made waste has, in fact, been studied comprehensively [32], therefore, the variant

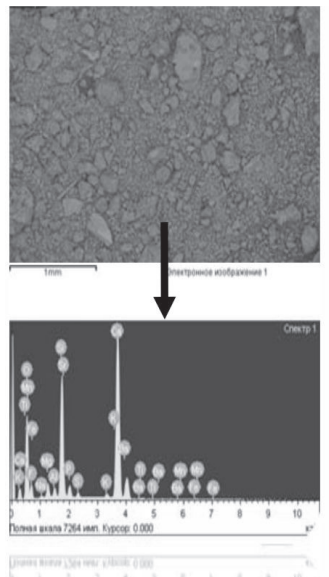

A

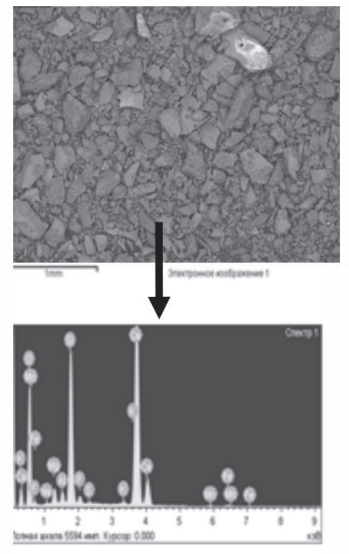

B

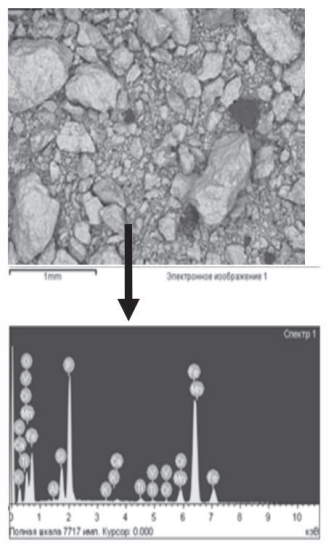

C

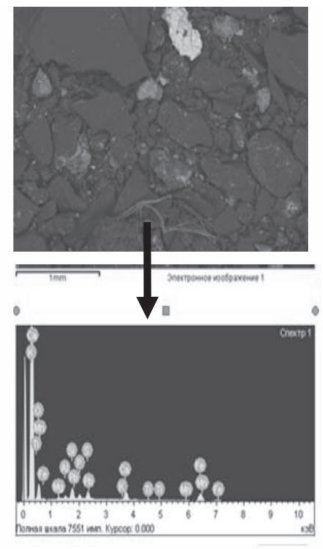

D

Fig. 4. The results of REM analysis. 


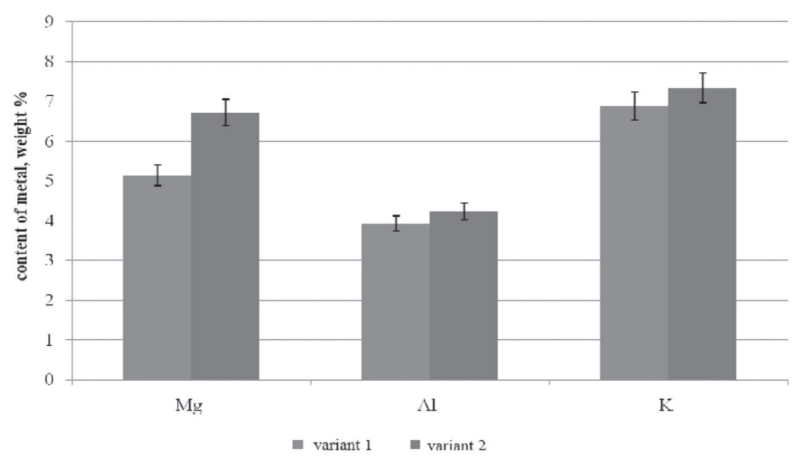

Fig. 5. The influence of medium 9K (variant 1) and Alicyclobacillus tolerans ST (variant 2) on the extraction of magnesium, aluminum and potassium from phosphoruscontaining solutions.

using the Alicyclobacillus tolerans ST strain in our studies is used only to confirm the indisputable role of this microorganism in the processes of bioleaching of phosphorus-containing waste in acidophilic conditions. Really, the use of acidophilic bacteria Alicyclobacillus tolerans $S T$ allow to increase the yield of magnesium, aluminum and potassium ions into the productive solution on $30.64 \% ; 7.58 \%$ and $6.45 \%$ respectively, in comparison with variant where only the elective medium is used (Fig. 5). In addition, at using of sulfobacteria the increase in the yield of calcium and phosphorus into the solution on $6.00 \%$ and $17.10 \%$, respectively, is noted.

On the other hand, it is known that acidophilic conditions with a $\mathrm{pH}$ of 1.5-3.5 are necessary for bioleaching of metal-containing substrates with the help of thio and sulfobacteria [33]. The acidity of the medium is maintained with the help of sulfuric acid added or formed as a result of the metabolism of sulfobacteria. This is probably one of the downsides of using thio and sulfobacteria in biohydrometallurgy. This issue may be particularly acute in the case of possible bioleaching of phosphorus-containing slags in Shymkent due to the close location of settlements with surface and underground sources of water resources.

The analysis of the literature data shows versatile studies of the possibility of using microscopic Aspergillus fungi for the bio-recovery of metals from

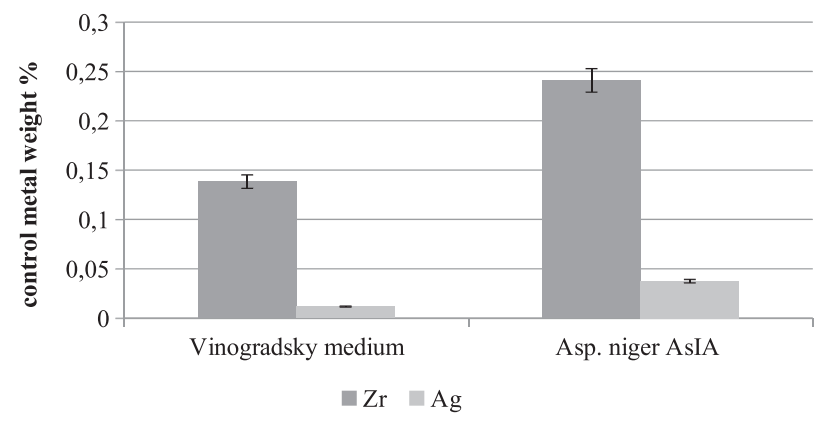

Fig. 6. Extraction of zirconium and silver in variants with use of elective medium and micromycetes Asp. niger AsIA.

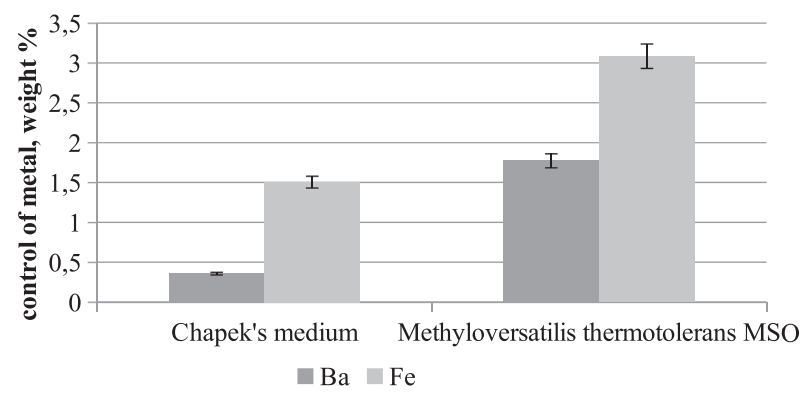

Fig. 7. Extraction of barium and iron with the use of the elective Chapek's medium and nitrifying bacteria Methyloversatilis thermotolerans MSO.

metal-containing waste [34]. The advantages of using this group of microorganisms include the availability and cheapness of cultivation, rapid adaptation to changing environmental conditions, optimum $\mathrm{pH}$ of 4.0 and above. In addition, the isolation of Aspergillus niger AsIA strain with confirmed characteristics of non-pathogenicity and non-allergenicity for humans and warm-blooded animals allowed us to consider this micromycete as a promising microorganism for biogeotechnological purposes. The use of micromycetes Asp. niger AsIA is effective at the extraction of metals of value such as zirconium and silver, at that the increase of these metals yield into solution in the variant with use of micromycetes is $74.11 \%$ and $18.76 \%$, respectively (Fig. 6).

In addition, the role of a group of bacteria from the Nitrosomonales family, which is still little known in biohydrometallurgy, was studied in this study. Nitrifying bacteria of phase 1 nitrification participate in the biogeochemical nitrogen cycle in Nature, where they participate in the conversion of ammonium ions into nitrite ions $[35,36]$. It is known that nitrite ions are active oxidants, which suggested their possible participation in the oxidation of sulfide minerals. Along with this, the optimum growth conditions of nitrifies takes place at neutral $\mathrm{pH}$ values, which, if positive results are obtained, in the future will allow to create

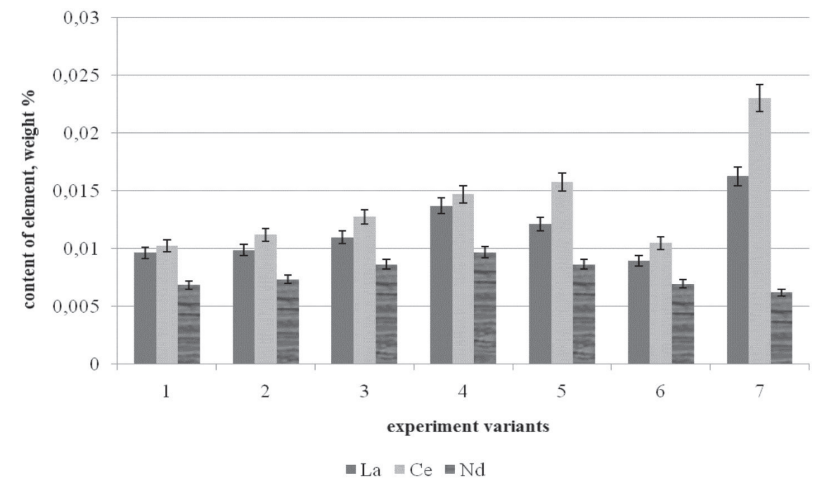

Fig. 8. Influence of elective media and microorganisms on the extraction of lanthanum, cerium and neodymium from phosphorus-containing wastes. 
an environmentally safe technology for processing man-made waste. The use of nitrifying bacteria Methyloversatilis thermotolerans MSO contributes to the increase of the extraction of barium and iron ions into the solution almost twice or on $96.67 \%$ and $104.78 \%$, respectively (Fig. 7).

It is found that the use of elective media together with microorganisms increase the yield of rare earth metals into the productive solution in comparison with the control version, where only elective media are used. So, at using of the strain Alicyclobacillus tolerans ST the increase of lanthanum extraction is 0.00023 wt. $\%$ or $2.38 \%$ from total yield; the increase of cerium extraction is 0.00097 wt. \% or $9.48 \%$ from total yield, the increase of neodymium extraction is $0.00051 \mathrm{wt}$. $\%$ or $7.45 \%$ from total yield (Fig. 8). At the extraction of lanthanum and neodymium with the help of Asp. niger AsIA in the liquid Czapek's medium it is found the reduce of elements extraction in to the productive solution on $11.58 \%$ and $10.64 \%$, respectively. The use of nitrifying bacteria Methyloversatilis thermotolerans MSO promotes the increase of the lanthanum yield into the solution on $81.87 \%$; cerium $-19.84 \%$.

\section{Conclusions}

On the formation of the phosphorus-containing waste's fractional composition of the South of Kazakhstan not only the conditions of raw materials processing, but also the weather and climatic parameters and time characteristics of storage are influenced.

The dominant part of wastes are silicate and calcium-containing compounds represented by pseudowollastonite, cuspidine, ferrophosphorus, melilite, akermanite, rankinite, fluorapatite, whitlockite, fluorite and silicocarnotite.

The role of different groups of microorganisms in bioleaching of valuable metals from phosphoruscontaining wastes was studied in the research. The choice of phase 1 nitrifies and micromycetes for biogydrometallurgical purposes was justified by the conditions of their cultivation in neutral or weakly acidic environments, which can create an alternative to traditional methods of sulfuric acid leaching or bioleaching by acidophilic bacteria.

The used strains of microorganisms selectively leach metals. The variant with the use of acidophilic bacteria Alicyclobacillus tolerans ST have demonstrated the effectiveness of their use in biohydrometallurgy, because it showed an increase in the extraction of such metals as magnesium, aluminum, potassium, calcium phosphorus, from rare earth elements such as lanthanum, cerium and neodymium. The use of micromycetes Asp. Niger AsIA proves to be effective in the extraction of metal of value such as zirconium and silver. Application of nitrifying bacteria Methyloversatilis thermotolerans MSO helps to increase the extraction of barium and iron ions into the solution.

\section{Acknowledgements}

This study was made under a grant from the Kazakhstan Republic Ministry of education and science No. 203-24 from 03.03.2017: “Development of a method of biological leaching of lanthanum, cerium and neodymium from the polymetallic, lead- zinc, phosphor containing wastes in southern Kazakhstan".

\section{Conflict of Interest}

The authors declare no conflict of interest.

\section{References}

1. BORRA C.R., PONTIKES Y., GERVEN T.V. Leaching of rare earths from bauxite residue (red mud). J. Minerals Engineering 15 (76), 20, 2015.

2. MÄKINEN J., WENDLING L., LAVONEN T. AND KINNUNEN P. Sequential Bioleaching of Phosphorus and Uranium. J. Minerals 9, 331, 2019.

3. KULAKSIZ S., BAU M. Rare earth elements in the Rhine River, Germany: First case of anthropogenic lanthanum as a dissolved micro contaminant in the hydrosphere. Environ. Int. 37, 973, 2011.

4. PIPERD Z., BAU M. Normalized Rare Earth Elements in Water, Sediments, and Wine: Identifying Sources and Environmental Redox Conditions. American Journal of Analytical Chemistry. 4, 69, 2013.

5. YANG F., KUBOTA F., BABA Y., KAMIYA N., GOTO $M$. Selective extraction and recovery of rare earth metals from phosphor powders in waste fluorescent lamps using an ionic liquid system. Journal of Hazardous Materials. 254, 79, 2013.

6. HAMZA M.F., El-AASSY I.E., GUIBAL E., Integrated treatment of tailing material for the selective recovery of uranium, rare earth elements and heavy metals, J. Minerals Engineering 133, 138, 2019.

7. IQDARI A., VELDE B., BENALIOULHAJ N., DUJAN S. C., YAMINE N.C.R. Exchange of light rare earth for $\mathrm{Ca}$ in apatite. J. Geoscience 335, 381, 2003.

8. KIDDER D.L., KRISHNASWAMY R., MAPES R.H. Elemental mobility in phosphatic shale during concretion growth and implications for provenance analysis. J. Chem. Geol. 198, 335, 2003.

9. HUIXIN J., HUA W., JUNGI L., Investigation on ore characteristics of REE-bearing phosphorite deposit in Xinhua Gezhongwu ore zone. Chinese Journal of Rare Metals. 31 (3), 2007.

10. GALFATI I., SASSI A. B., ZAIER A., BOURHARDON J.L., BILAL E., JORON J.L., SASSI S. Geochemistry and mineralogy of Paleocene-Eocene Oum El Khechebphosphorites (Gafsa-Metlaoui Basin) Tunisia. Geochemical Journal. 44, 189, 2010.

11. WASIM S., GUODONG Zh., GHUFRANUD D., XIANGXIAN M., MUHAMMAD R., WANG X., Metals Extraction from Sulfide Ores with Microorganisms: The Bioleaching Technology and Recent Developments. The Indian Institute of Metals- IIM 72 (3), 559, 2019.

12. FATEMEH P., SEYYED M.M., A novel step-wise indirect bioleaching using biogenic ferric agent for enhancement recovery of valuable metals from waste light emitting 
diode (WLED). Journal of Hazardous Materials. 378, 648, 2019.

13. WANG J., ZHU S., ZHANG Y., ZHAO H.-B., HU M.H., YANG C.-R., QIN W.-Q., QIU G.-Z. Bioleaching of low-grade copper sulfide ores by Acidithiobacillus ferrooxidans and Acidithiobacillus thiooxidans. Journal of Central South University, 21, 728, 2014.

14. JAHANI S., FATEMI F., FIROZ-E-ZARE M.A., ZOLFAGHARI M.R. Isolation and Characterization of Acidithiobacillus ferrooxidans Strain FJS from Ramsar, Electronic Journal of Biology. 11 (4), 138, 2015.

15. HARAGOBINDA S., ASHISH P., DONG J.K., SEOUNGWON L. Comparison of Bioleaching of Metals from Spent Petroleum Catalyst Using Acidithiobacillus ferrooxidans and Acidithiobacillus thiooxidans. International Journal of Chemical, Nuclear, Metallurgical and Materials Engineering. 7, 499, 2013.

16. KAIBIN F., HAI L., DEQIANG L., WUFEI J., PING Z. Comparison of bioleaching of copper sulphides by Acidithiobacillus ferrooxidans. J. Environ Geochem Health 13, 664, 2014.

17. FARAMARZI M.A, STAGARS M., PENSINI E., KREBS W., BRANDL H. Metal solubilization from metal-containing solid materials by cyanogenic Chromobacterium violaceum. J. of Biotechnology 113, 321, 2004.

18. QIAN L., WOLFGANG S., RUIYONG ZH. Enhancement of Biofilm Formation on Pyrite by Sulfobacillus thermosulfidooxidans. J. Minerals 6 (3), 71, 2016.

19. ROBERTO A BOBADILLA-FAZZINI., MARIA PAZ CORTÉS., ALEJANDRO MAASS, PILAR PARADA. Sulfobacillus thermosulfidooxidans strain Cutipay enhances chalcopyrite bioleaching under moderate thermophilic conditions in the presence of chloride ion. J. AMB Express 4, 84, 2014.

20. MAURICIO L., MARÍA P.C., DANTE T., ALEX D.G., MARKO B., ANGÉLICA R.J., CHRISTIAN H., MAURICIO G., PILAR P.,ROBERTO A.B.F., VERÓNICA C., ALEJANDRO M. The bioleaching potential of a bacterial consortium. Bioresource Technology 218, 659, 2016.

21. JOHNSON J.T., KELLY S.,. Bioleaching of WPCB by Aspergillus niger. 10.13140/RG.2.2.21510.68166. 2017.

22. REED D.W., FUJITA YOSHIKO, DAUBARAS DAYNA L., JIAO YONGQIN, THOMPSON VICKI S. Bioleaching of rare earth elements from waste phosphors and cracking catalysts. 166, 34, 2016.

23. HASCHKE M., AHMADIAN J., ZEIDLER L., HUBRIG T. Procedia Engineering. In-Situ Recovery of Critical Technology Elements. "Symphos 2015", $3^{\text {rd }}$ International Symposium on Innovation and Technology in the Phosphate Industry. 138, 248, 2016.

24. STS 10398-2016. Reagents and highly pure substances. A complexometric method for determining the basic substance. Interstate standard. Reagents and super pure substances. Complexometric method for determination of main substance. Reprint February 2019.

25. STS R 56219-2014 (ISO 17294-2:2003). Determination of 62 elements by inductively coupled plasma mass spectrometry (ICP-MS) method. - Part 2. 01-01-2016.
26. ST RK -ISO 17294-2-2006 (ISO17294-2-2006 IDT). State standard of the Republic of Kazakhstan. The use of inductively coupled plasma mass spectrometers (ICP-MS). 2006.

27. STS R ISO 7523-2016. STS 33208-2014. STS 28353.3-2017. STS R 57655-2017. FER F 16.1: 2.2: 2.3: 3.36-02. FER F 14.1: 2: 4.140-98. Atomic absorption spectroscopy: objects of analysis, fulfilled standards. January, 2019.

28. BARBARA L.D., CHRISTINE M.C. X- ray Powder Diffraction (XRD). Integrating Research and Education. Geochemical Instrumentation and Analysis. https: //serc. carleton.edu/18400. April 05, 2019.

29. SCHABENBERGER O., PIERCE F.J. Contemporary statistical models for the plant and soil sciences. CRC Press, Boca Raton, 256, 2002.

30. KARAVAIKO G.I, BOGDANOVA T.I., TOUROVA T.P., KONDRAT'EVA T.F., TSAPLINA I.A., EGOROVA M.A., KRASIL'NIKOVA E.N., ZAKHARCHUK L.M.. Reclassification of 'Sulfobacillus thermosulfidooxidans subsp. thermotolerans' strain K1 as Alicyclobacillus tolerans sp. nov. and Sulfobacillus disulfidooxidans Dufresne et al. 1996 as Alicyclobacillus disulfidooxidans comb. nov., and emended description of the genus Alicyclobacillus. International Journal of Systematic and Evolutionary Microbiology. 55, 941, 2005.

31. TSAPLINA I.A., ZHURAVLEVA A.E., ISMAILOV A.D., ZAKHARCHUK L.M., KRASIL'NIKOVA E.N., BOGDANOVA T.I., KARAVAIKO G.I. The dependence of intracellular ATP level on the nutrition mode of the acidophilic bacteria Sulfobacillus thermotolerans and Alicyclobacillus tolerans. J. Microbiology. 76 (6), 654, 2007.

32. HOLANDA R., HEDRICH S., NANCUCHEO I., OLIVEIRA G., GRAIL B., JOHNSON D. Isolation and characterization of mineral-oxidizing "Acidibacillus" spp. from mine sites and geothermal environments in different global locations. J. Research in Microbiology. 167 (7), 613, 2016.

33. PENG T., ZHOU D., LIU Y., YU R., QIU G., ZENG W., Effects of $\mathrm{pH}$ value on the expression of key iron/sulfur oxidation genes during bioleaching of chalcopyrite on thermophilic condition. Ann Microbiol 69, 627, 2019.

34. VAKILCHAP F., MOUSAVI S.M., SHOJAOSADATI S.A. Role of Aspergillus niger in recovery enhancement of valuable metals from produced red mud in Bayer process. Bioresource Technology, 218, 991, 2016.

35. MAOXIA CH., YANGWU CH., SHIYANG D., SHUHUAN L., HOUZHEN ZH., ZHOULIANG T., XUDONG L., Mixed nitrifying bacteria culture under different temperature dropping strategies: Nitrification performance, activity, and community. J. Chemosphere., 195, 800, 2018.

36. WEIFANG H., WENLONG ZH., LINHAI ZH, XIANBIAO L., CHUAN T., DERRICK Y.F.L., YUEHMIN C., CONGSHENG Z., Short-term changes in simulated inundation frequency differentially affect inorganic nitrogen, nitrification, and denitrification in estuarine marshes., Ecological Indicators., 107, 105571, 2019. 